\title{
CADAVER DISROBING: A NOVEL INITIATIVE TO STIMULATE AFFECTIVE DOM AIN IN THE FIRST YEAR M.B.B.S STUDENTS
}

Dinesh kumar. V *1, V.K.Nim ${ }^{1}$, S. Jayagandhi ${ }^{1}$, Thomas Alexander ${ }^{2}$,

${ }^{* 1}$ Department of Anatomy, Pondicherry Institute of M edical Sciences, Pondicherry, India.

2 Former Dean, Medical Education Unit, Pondicherry Institute of Medical Sciences, Pondicherry, India.

\section{ABSTRACT}

First exposure to human cadaver has the potential to be a psychological trauma inducing stressor. On the other hand, this exposure can be the Launchpad to develop reflective writing and empathy amidst students. This study aims at documenting students' experience of this potential stressor in cognitive, behavioural, moral and affective domains. This program has also helped in reducing the disgust of most students towards cadavers. This novel desensitization program not only reduces the emotional impact among students but also helps them to prune their reflective writing and observation skills right from the early days of medical education.

KEY WORDS: cadaver dissection, hidden curriculum, reflective writing, empathy.

Address for Correspondence: Dr.V.Dinesh Kumar, Assistant Professor, Department Of Anatomy Pondicherry Institute Of M edical Sciences, Puducherry-605014, India.

E-M ail: dinesh.88560@gmail.com

\begin{tabular}{|c|c|c|}
\hline \multicolumn{3}{|c|}{ Access this Article online } \\
\hline \multirow{2}{*}{$\begin{array}{l}\text { Quick Response code } \\
\text { 口, }\end{array}$} & \multicolumn{2}{|c|}{$\begin{array}{l}\text { Web site: International Journal of Anatomy and Research } \\
\text { ISSN 2321-4287 } \\
\text { www.ijmhr.org/ijar.htm }\end{array}$} \\
\hline & $\begin{array}{l}\text { Received: } 05 \text { Nov } 2016 \\
\text { Peer Review: } 05 \text { Nov } 2016\end{array}$ & $\begin{array}{l}\text { Accepted: } 13 \text { Dec } 2016 \\
\text { Published (0): } 31 \text { Jan } 2017\end{array}$ \\
\hline DOI: 10.16965/ijar.2016.469 & Revised: None & Published (P): 31 Jan 2017 \\
\hline
\end{tabular}

\section{INTRODUCTION}

Learning gross anatomy is intricately associated with dissection. It is the field of medical education with a deep rooted history, which dates back to 300 B.C. There were days where dissection was conducted in a clandestine manner, days where "dissection" was awarded as a capital punishment and days where buried bodies were dug out of grave to quench the explorative thirst of medical students. Acts were made to ease down the procedures for procuring cadavers, since then. Dissection which were made in public was then confined to medical schools. Hafferty [1] calls the experience of dissection an emotional rite of passage which promotes the process of changing over from layperson to doctor. Though the history of dissection is galore, it was in late $20^{\text {th }}$ century when students were taught to treat the cadavers with due emotions. Memorial services at the end of anatomy courses began in the United Kingdom in 1965 and in the United States in the 1970s, with the goal of heightening students' sensitivity toward their cadavers [2].

The cadavers obtained may have some "markings" in them, which make the students curious to think about the past of them. If the cadavers were the result of wilful body donation, the details and reason for death can be traced back. But if they are unclaimed, poor and neglected ones who don't even have opportunities for their last rights, the details can be seldom traced. Nevertheless, this background provides enough grounds to make the students empathize with 
their "first patient".

Dissection hall is a place of emotional turbulence. Emotions can be varying from an excitement to anxiety, upon the initial encounter. Students learn rapidly to develop a coping mechanism that enables them to depersonalize cadaver dissection [3]. Students who have experience with the dead body will be better equipped to deal with issues surrounding death and more aware of medical uncertainty, which will make them better clinicians [4].

Reflection is an innate and personal response to encounters, experiences, situations, scenarios and new information [5]. This skill can be groomed right from the first year of medical education by asking the students to document their emotion and observations in a narrative way. This also can be considered as a miniature version of clinical reasoning which is described as a narrative, experiential and interpretive activity [6]. An initial and ongoing description of the corpse, with an exact description of the findings without diagnosis, and without influence by 'norms' is necessary to promote students' skill in observation and documentation [7].

On these grounds, a novel initiative was started to provoke the attitude of the student to empathize with cadavers and make the student more "professional" oriented.

\section{MATERIALS AND METHODS}

The study was done on 28-7-15 by faculties of Department of Anatomy and M edical Education Unit (MEU) in the dissection hall of Pondicherry Institute of M edical Sciences. This involved 100 newly joined M BBS students and was intended to document the affective domain of them on seeing the cadaver for the first time.

The students were divided into 6 groups of 16 or 17 each. They were made to sit around the dissection table on which cadavers, fully covered by white cloth were placed. The students were given a sheet of paper, to document their feelings, along with name and date. An emotionally appealing introductory presentation (audio and visual) was delivered to the students, where a brief narration was made from the cadaver's point of view. This was made by the Head of MEU following which he explained the further procedures. The draped cotton sheet was then removed gradually in stages and questions were put forth and the students were asked to document their feelings. Head of cadaver was exposed followed by limbs, thorax, abdomen and finally genitals. At the end students were asked to give their final comments.

\section{OBSERVATIONS}

All 100 students who were given the questionnaire, returned the filled up response sheets. Unlike previous studies, which involves issuing a questionnaire, we relied much on 'reflective' writing where the student is free to pen down his observations and also affective feelings. We had interesting comments from the students which are classifiable under affective, cognitive, moral and behavioural responses.

\begin{tabular}{|c|c|}
\hline $\begin{array}{c}\text { CLASSIFICATION OF } \\
\text { RESPONSES }\end{array}$ & COMMENTS \\
\hline AFFECTIVE & $\begin{array}{ll}\text { 1. } & \text { "first teacher in medical field", } \\
\text { 2. } & \text { "face reminds me of my friend's father" } \\
\text { 3. } & \text { "a doctor should be exposed to any part of the body without embarrassment" } \\
\text { 4. } & \text { "feel sentimental; even if he is dead, he helps us to dissect and learn" } \\
\text { 5. } & \text { "feeling pity" } \\
\text { 6. } & \text { "First felt sad; then on hearing the words in the presentation 'why do you hate on seeing } \\
\text { me. I am helping vou to study' I felt thankful" } \\
\text { 7. } & \text { "not frightened; look like someone sleeping with eyes open" } \\
\text { 8. } & \text { "felt sorry for him to die so early and thinking about family" }\end{array}$ \\
\hline COGNITIVE & $\begin{array}{ll}\text { 1. } & \text { "Stitches in the thigh - result of any surgery?"( } n=2) \\
\text { 2. } & \text { "the person appear to have died because of inadequate medical facilities" } \\
\text { 3. } & \text { "How he would have been while he was alive?" } \\
\text { 4. } & \text { "he would have been poor" } \\
\text { 5. } & \text { "curious to know the cause of death" }\end{array}$ \\
\hline BEHAVIOURAL & $\begin{array}{ll}\text { 1. } & \text { "feel so sad" (n=10) } \\
\text { 2. } & \text { "excited" } \\
\text { 3. } & \text { "scary" }(n=3) \\
\text { 4. } & \text { "smell is nauseating"( } n=4) \\
\text { 5. } & \text { "felt apprehended"( } n=3) \\
\text { 6. } & \text { "felt weird"( }(n=2) \\
\text { 7. } & \text { "feeling anxious" } \\
\text { 8. } & \text { "not connected with emotions; eager to dissect it" } \\
\text { 9. } & \text { "feeling creepy" } \\
\text { 10. "felt agitated" } \\
\text { 11. "mixed feeling of excitement, tension and fear"( } n=3) \\
\text { 12. "feelings changed stepwise; upon uncovering head \& neck, felt nervous, sympathetic and } \\
\text { sacred; upon uncovering torso and upper limb felt anxious; lower limb-confused and on total } \\
\text { uncoverina felt calm and relieved" } \\
\text { 13. "felt unhappy to see one of our human dead" } \\
\text { 14. "inexplicable hard feeling" } \\
\text { 15. "scared on seeing his palms" }\end{array}$ \\
\hline MORAL & $\begin{array}{ll}\text { 1. } & \text { "the sacrifice of this person forms foundation of my profession" }(n=0) \\
\text { 2. } & \text { "must make use of his sacrifice"( } n=15) \\
\text { 3. } & \text { "first was surprised by the presentation and felt motivated to become a good doctor" } \\
\text { 4. } & \text { "felt gratified to the person for donating his body for dissection"( } n=5) \\
\text { 5. } & \text { "First thought that once this person had life and now lying dead in the table and then felt } \\
\text { sad. Should not let his sacrifice ao waste" } \\
\text { 6. } & \text { "thank for his sacrifice and respect it" }\end{array}$ \\
\hline
\end{tabular}

At the end of dissection schedule, we evaluated the students' response by asking them to grade the effectiveness of cadaver disrobing program 
in reducing the disgust towards cadavers and helping them cope up better. We asked them to grade it in Likert scale (0-5). 43 students graded it 5, 30 students graded it 4 and 22 students graded it 3 upon 5 .

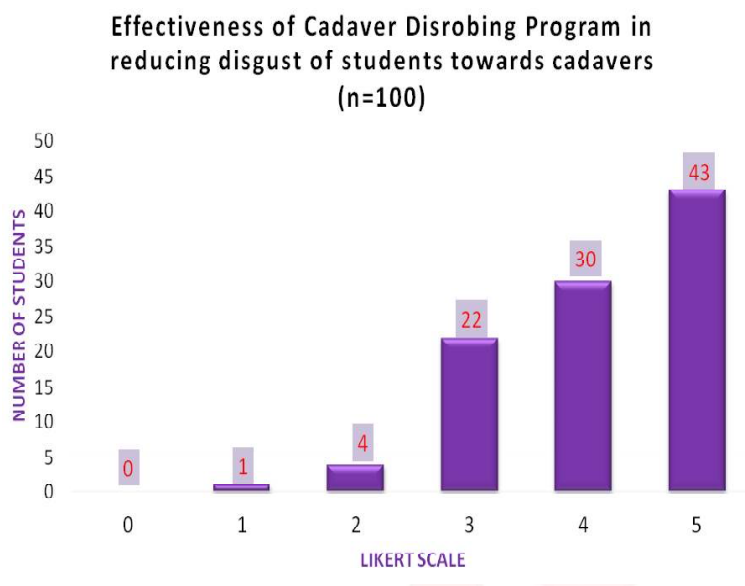

\section{DISCUSSION}

The importance of human dissection in gross anatomy learning is unmatched even in the era of technical advances. Computer assisted learning, 3-D image based learning falls short of conventional dissection teaching, as handson dissection experience can teach a lot more than just "seeing" the constructed images. According to Rizzolo LJ [8], Anatomy instructors can play a crucial role in helping medical schools meet the critical need to cultivate humanistic values, especially in the arena of end-of-life care. He also states that, as dissection remains an essential technique to teach threedimensional concepts, the cadaver dissection lab is an ideal place to introduce concepts of humanistic care.

As the students enter the dissection lab, their responses on seeing the cadaver for the first time is varied, which is determined mainly by their attitude. Attitude is determined by prior experiences, cognition, and emotional valence. Studies [9-11] have documented the effects of dissection-room experiences in medical students. These experiences, which can either be positive or negative appraisals, help the medical students in handling the stressors in future. Studies $[1,12]$ also show that dissection lab can serve as the first teaching site with regards to medical career socialization and professionalization. These experiences might form a part of informal curriculum, where the students learn through observations and interactions [12]. Attention to medical humanities helps to develop and nurture skills of observation, analysis, empathy, and self-reflection, skills that are essential for humane medical care [13]. Medical humanities might, for instance, help in 'humanizing' the student cadaver encounter by bearing witness to the 'cadaver experience' for anatomists of the past, but also offering forgotten alternatives for placing present-day reactions in perspective [14].

According to Bolton, [15] emphasis of medical humanities should be on critical conceptualization and analysis, reflexivity and reflective capacity. Our study has been conducted as an inter-disciplinary approach with dual objectives. First, to smoothen out the negative emotional appraisal responses on seeing the cadaver for the first time and second, to inculcate medical humanities right from the beginning. Unlike, other studies where students have to choose the appropriate response, we relied on "narrative" methods. As the observations which need to be documented are open-ended, it will not result in priming. Also, our prime aim was to inculcate critical thinking and pen down the personal observations.

The goals of our program were in accordance with Kristi J Ferguson et al. [16] who stated that reflection on dissection lab experiences may

1. Help students observe the donor as a whole being and not just as the bones and organs they studied

2. Have students make careful observations

3. Help students appreciate the contribution made to their education by the donors and their families through body donation.

In the present study, the students' responses varied according to their attitude. M any students had documented their behavioural responses. It varied from excitement to feeling sad. In a study by Vinay Kumar et al. [17], $61.33 \%$ of students had fear as their behavioural response followed by interest in $60 \%$ and neutral in 41.33\%. Another study by Egwu et al., [18] showed that $35.7 \%$ of the students were excited on their first exposure to dissection. The other feelings were discomfort (28.8\%) and scared $(12.2 \%)$. The nauseating feel in some students 
can be attributed to the exposure of preservatives for the first time. The variations in affect might probably due to the acquaintance already established by their senior colleagues in some students.

An orientation program or psychological counselling prior to the dissection class might alleviate these negative appraisal responses and make the students cope up better. A study by Melani et al. [19], showed significant reduction of anxiety in students who underwent a prior counselling before first dissection. In our study, $43 \%$ of students reported that cadaver disrobing program was effective $(5 / 5)$ in reducing the disgust towards cadavers.

The contact with the cadaver is a very special and unforgettable moment in medical student's academic life and may be the first chance to develop the required ethical respect for his/her future patients [20]. Recent results indicate that students believe the "body as teacher" concept is more effective in engendering respect and empathy towards the body and towards future patients, and in facilitating students' emotional development [21]. The audio-visual presentation we had prior to sequential exposure of cadaver insisted on the gratitude and empathy. When students were asked to reflect their feel, 10/100 students had affective feelings at that particular frame. 30/100 students felt that they should value the sacrifice done by the person and must make use of it to the fullest extent. The feedback we got made us think that, it would be better if all medical schools could insist the students on body donation programs, the difficulty in procuring cadavers and ethical aspects.

The concept of reflective writing also improves mindfulness (a state of accurate and empathic listening and observation), makes them feel less vulnerable and allows listeners to acknowledge and understand the testimony of the struggle presented at a much deeper and empathic level, rather than turning away [5]. In our study, 5/100 students made certain observations in the cadaver, as it was gradually disrobed, which made them think of the cause of death, scars and plausible condition when he / she was live.

\section{CONCLUSION}

Dissection lab experiences can elicit behaviou- ral, affective or moral responses. A prior orientation before it and a practice of reflective writing can make the students emotionally motivated which in turn can make them implement humanistic values in their profession. Our initiative is a venture which serves threefold objectives. First, it helps to cope up the negative behavioural responses of the students. Second, it serves to inculcate values and third, serves as primer for reflective writing.

\section{Conflicts of Interests: None}

\section{REFERENCES}

[1]. Hafferty FW. Cadaver stories and the emotional socialization of medical students. J Health Soc Behav. 1988;29(4):344-56.

[2]. Warner, J., and L. Rizzolo. Anatomical instruction and training for professionalism from the nineteenth to the twenty-first centuries. Clin. Anat. 2006;19:403-14.

[3]. Houwink AP, Kurup AN, Kollars JP, Kral Kollars CA, Carmichael SW, Pawlina W. Help of third-year medical students decreases first-year medical students' negative psychological reactions on the first day of gross anatomy dissection. Clin Anat, 2004;17:328333.

[4]. Parker LM. What's wrong with the dead body? Use of the human cadaver in medical education. Med J Aust 2002;176(2):74-6.

[5]. Kathiravan Chinniah and Sivalingam Nalliah. Reflective writing in case summary assignments. leJSM E 2012;6(1):15-20.

[6]. Avrahmi E, Reis SP. Narrative medicine. IMAJ. 2009;11:216-9.

[7]. Escobar-Poni B, Poni ES. The role of gross anatomy in promoting professionalism: a neglected opportunity! Clin Anat, 2006;19(5):461-467

[8]. Rizzolo LJ. Human dissection: an approach to interweaving the traditional and humanistic goals of medical education. Anat Rec. 2002 Dec 15;269(6):242-8.

[9]. Horne DJ, Tiller JW, Eizenberg $N$ et al. Reactions of first-year medical students to their initial encounter with a cadaver in the dissecting room. Academic Medicine. 1990;65(10):645-646.

[10]. M adill A, Latchford G. Identity change and the human dissection experience over the first year of medical training. Soc Sci Med. 2005;60(7):1637-47.

[11]. Dinsmore CE, Daugherty S, Zeitz HJ. Student responses to the gross anatomy laboratory in a medical curriculum. Clinical Anatomy. 2001;14(3):231-236.

[12]. Hafferty FW: Beyond curriculum reform: Confronting medicine's hidden curriculum. Acad Med 1998; 73:403-407.

[13]. Aull F. Medical Humanities - Mission Statement. http://medhum.med.nyu.edu/ accessed Sept. 3rd, 2013. 
[14]. Terry JS. The humanities and gross anatomy: Forgotten alternatives. J Med Hum, 1985;6(2):90-98.

[15]. Bolton, G. Medicine and literature: writing and reading. Journal of Evaluation in Clinical Practice, 2004;11;171-179.

[16]. Kristi J Ferguson, William Iverson, Marc Pizzimenti. Constructing Stories of Past Lives: Cadaver as First Patient: "Clinical Summary of Dissection" Writing Assignment for M edical Students. The Permanente Journal 2008;12(2):89-92.

[17]. Vinay Kumar V, Martin Lucas A, Vishal Kumar, Pradeep Kulal. Attitude of First year Indian M edical students towards Cadaver Dissection. Int J Anat Res 2015;3(3):1255-1258.

[18]. O.A. Egwu, A. C. Ugwu, A. N. Eteudo, E.O. Ewunonu and C.O. Njoku. Perceptions of medical students undergoing cadaveric training: a sociocognitive perspective. Internet Journal of M edical Update 2008;3(2):8-12.
[19]. M elani Rajendran S, Semmal M, Buhari AJ, Bhashi S, Rajendran P. Evaluation of the Emotional Impact of Cadaver Dissection in Medical Students at the Entry Level International Journal of Anatomical Sciences 2011;2(2):26-30.

[20]. Erich Brenner and Diogo Pais. The philosophy and ethics of anatomy teaching. Eur J Anat, 2014;18(4):353-360.

[21]. Bohl M, Bosch P, Hildebrandt S. M edical students' perceptions of the body donor as a "First Patient" or "Teacher": A pilot study. Anat Sci Educ, 2011;4(4):208-213.

How to cite this article:

Dinesh kumar. V, V.K.Nim, S. Jayagandhi, Thomas Alexander. CADAVER DISROBING: A NOVEL INITIATIVE TO STIM ULATE AFFECTIVE DOM AIN IN THE FIRST YEAR M .B.B.S STUDENTS. Int J Anat Res 2017;5(1):3333-3337. DOI: 10.16965/ijar.2016.469 